\title{
Bebeit Haniyim (Na casa dos pobres)
}

\section{Yaacov Steinberg*}

Aquele foi um inverno branco. Dos carvalhos que mamãe comprara no dia do mercado, não havia sobrado sequer um único palito, e na nossa casa havia um frio úmido e maçante. Do lado de fora, predominavam os dias congelantes e sem ventos e no céu pairava um sol distante e frio, que se parecia com um olho grande e encantado, pairando no ar com uma luz morta. Ao anoitecer, o céu voltava à vida e ria como que num carmesim de fogo, então, a lua se levantava - uma lua prateada e redonda, que parecia mais viva e mais consciente do que o sol durante o dia. Em nossa casa, o frio se revelava ao redor das janelas que estavam cobertas de listras de geadas brancas, que se assemelhavam a tiras de neve suja, dando à casa uma aparência escura e triste. Parecia que um inimigo invisível penetrara em nossa casa pelas fendas.

Ninguém na casa proferia uma palavra sequer em voz alta. Meu pai, homem alto, de nariz grande e bigode espesso, poderia ter aquecido a casa se estivesse conosco. Ele caminharia com passos largos e pesados pela sala (era assim como chamávamos o maior dos nossos três quartos). Esse fato tornou-se hábito para meu pai desde a época em que ele havia ficado sem meios de subsistência andar de um lado para o outro nos quartos, murmurando e sussurrando uma melodia que saía das narinas do seu nariz, o nariz aquilino, de uma maneira tão alegre e vibrante, que nosso coração tornava-se leve, mesmo quando na casa

* Yaacov Steinberg é um dos grandes nomes da literatura hebraica da primeira metade do século XX. Ele nasceu em Bila Tserkva, região central da atual Ucrânia que fazia parte do Império Russo em 1887. Seu pai era açougueiro e ele iniciou seus estudos numa escola rabínica. Em 1901, aos 14 anos, abandonou a cidade natal chegando a Odessa, na época um dos principais centros da intelectualidade judaica. Ali ele conheceu a Haim Nachman Bialik e entrou em contato com a poesia e com a literatura hebraicas. Em 1903, passou de Odessa para Varsóvia onde conheceu o escritor I. L. Peretz. Em Varsóvia, participou da imprensa escrevendo tanto em ídiche quanto em hebraico. Em 1910, mudou-se para a Suíça onde estudou na Universidade de Berna. Retornou a Varsóvia para escrever no jornal ídiche Der Fraynd, que foi o primeiro jornal em ídiche a circular diariamente no Império Russo entre 1903 e 1912. Em 1914, Steinberg chegou à Palestina e, desde então, passou a escrever apenas em hebraico. Faleceu na cidade de Tel Aviv em 22 de junho de 1947. Este conto escrito em hebraico encontra-se disponível em: <https://bybe.benyehuda.org/print/10318>. 
não havia sequer pão para comer. Mas, naqueles dias, papai não estava em casa. Algumas vezes, ele empenhava algum objeto numa casa de penhores, viajando a seguir para Odessa ou Kherson, ${ }^{1}$ com esperança de encontrar algum trabalho. Em nossa casa, persistia uma deprimente e monótona tristeza, tristeza esta que reina em cada casa onde a mulher é quem carrega o fardo do sustento.

A tristeza em nossa casa tornou-se maior ainda pelo fato de que minha mãe era uma criatura boa e bonita e que, mesmo nos piores dias, ela não abaixava seu pescoço branco por causa da angústia, mostrando ter certa autoestima; pois ela era calma por natureza e amava meu pai intensamente, como no dia de seu casamento.

Meu pai, que era alto e de olhos aquilinos, possuía um espesso bigode preto. Quando papai chegava em casa com um pouco de dinheiro, mamãe mostravase gentil desde o primeiro instante de seu retorno. Ela demorava todos os dias para se levantar e papai lhe servia uma xícara de chá na cama; além disso, na hora do almoço, papai acariciava seu pescoço alvo na frente de todos os filhos... Nesses dias, mamãe afastava todas as preocupações de seu coração e papai se preocupava de que nada lhe faltasse. Mas quando papai viajava novamente para algum lugar, mamãe mostrava-se diferente desde a primeira manhã após a viagem de papai: um dia ela tomava um empréstimo e, no dia seguinte, recorria a uma casa de penhores, e um dia após outro, ela precisava recorrer a conselhos e tramas, sem os quais não há como sobreviver à pobreza um dia sequer - pois na nossa casa voltava a imperar uma fome silenciosa e o ar frio ficava impregnado de um forte cheiro azedo de seis crianças sujas e mal alimentadas. Cabisbaixos, nós nos posicionávamos uns contra os outros no frio úmido e mesmo eu, o filho mais velho, tendo atingido a idade de quatorze anos - recebia como almoço uma rala sopa de favas, mas da minha boca não saia qualquer queixa. Éramos crianças tranquilas e nos parecíamos com nossa quieta e bondosa mãe. As crianças menores choravam sem alarde, não como outras crianças más, e se uma criança levantava um grito em nossa casa - ela não balançava a cabeça em sinal de protesto... Mas, minha irmã mais velha, por outro lado e bem diferente, se parecia com papai.

Minha irmã também era alta e seus olhos negros, envoltos em umidade, assemelhavam-se aos olhos do papai, mas seu rosto era bem moldado e havia, sobre sua boca, uma expressão de vontade. Minha irmã era frágil e muito magra, de modo que seu peito redondo e seu rosto pareciam sublimes. Em

${ }^{1}$ Odessa e Kherson são duas cidades na atual Ucrânia. 


\section{Arquivo Maaravi}

Revista Digital de Estudos Judaicos da UFMG

ISSN: $1982-3053$

todas as roupas que minha irmã vestia, ela se mostrava atraente e sempre parecia que usava uma camisa simples apenas por graça. Além disso, minha irmã possuía, mimada que fora como se fosse filha de ricos, um tipo de caminhar que se assemelhava a um jogo, e quando ela dava alguns passos vacilantes, quem a visse poderia pensar estar vendo a sua frente uma tenra e bem cuidada moça, que possuía em suas veias o sangue de muitas gerações de prestígio e de distinção. E, de fato, esperava-se que minha irmã fosse agraciada com todas as graças que há no mundo. Assim que ela se deitava esticada no sofá, sua ampla cabeleira se espalhava e seus olhos brilhantes e refrescantes se fixavam em algum livro de canções. E ela só tinha que insinuar algo com a ponta de seu sapato, para que também eu, um rapaz já crescido e com marcas de um bigode preto, prestasse imediatamente atenção a sua voz. As crianças menores a obedeciam como a papai e até o velho tecelão, que era o proprietário da nossa casa, cuja privacidade de forma indireta, nós sempre invadíamos quando era preciso lhe pagar o aluguel, também ele, quando vinha para reivindicar os pagamentos devidos, mostrava especial reverência e tirava o chapéu diante de minha irmã Rachel. Essa atitude encorajava mamãe a botar para fora a esse incircunciso sem lhe dar dinheiro algum.

Certa vez aconteceu um fato que encheu mamãe de orgulho por anos: um dia, mamãe foi com Rachel para comprar tecido para a confecção de uma camisa (mamãe gastava o último centavo em benefício da filha mais velha, para que ao menos ela estivesse vestida como as moças mais abastadas). $\mathrm{O}$ fato ocorreu durante os dias chuvosos. Num lugar enlameado, havia uma espécie de ponte que podia ser atravessada entre escombros. Rachel manchou primeiro, ela estava vestida com seu casaco curto e seu pequeno chapéu que tinham sido confeccionados no ano anterior. As pontas de seus dedos apareciam pelas finas e amassadas luvas, mas sua leve e fina estatura se projetavam sobre a ponte enlameada. Mamãe seguia atrás dela, envolta por um grosso e surrado casaco. Seu vestido puído trazia círculos e sinais de lodo e seus olhos lacrimejavam devido ao vento. Elas caminhavam e se aproximavam da loja - mas, de repente, começou a vir em direção a elas, o jovem ministro provincial, que retornava para a cidade. Eis que ele avançava a passos largos... Eles se encontram na ponte e a ponte tinha apenas duas tábuas de largura. A distância da loja era de apenas poucos passos, Rachel poderia ter se detido, mas ela não mudou de rumo e deu de cara com o ministro. Ela levantou a borda de seu vestido e esperou e o ministro, que era de alta estatura, parou, olhou para a cabeça da jovem e para a mulher atrás dela, que estava cabisbaixa, mostrando sinais de raiva, seu ondulado bigode tremia - ele se preparava para abrir a boca a fim de repreendê-la e até levantou seu pé com o intuito de pisar em Rachel. Mas 
Rachel levantou sua cabeça, olhou nos olhos do ministro e disse com ligeira indignação: - Afaste-se e me deixe passar!

Os olhos do ministro se arregalam, um leve tremor passou pelo seu reto bigode, mas, um momento depois, ele sorriu, andou ligeiramente para o lado e se posicionou sobre os degraus da loja. Ele deixou Rachel passar... Quantas vezes o rosto de mamãe iluminou-se ao relatar este acontecimento! E quantas outras histórias mamãe tinha em relação aos não judeus, que alguma vez se inclinaram diante de minha irmã Rachel. Mas quando se trata dos judeus, o assunto era completamente diferente. Durante uma conversa no mercado, se alguém perguntasse como Rachel estava, o rosto de mamãe enrubescia no meio da conversa: ela temia que alguma palavra sobre o caráter de sua filha fosse dita, que alguém perguntasse a razão pela qual a moça estava sempre ociosa e nada fazia. Uma jovem que concluíra os estudos no ginásio! Isso já ocorrera na loja e também no penhor. Uma vez não quiseram lhe fornecer peixes salgados e lhe disseram: "que a moça arrume aulas para ministrar e com esse dinheiro salde as dívidas".

Um dia chegou em casa o corpulento açougueiro a fim de cobrar a dívida que se acumulara no caderno por três anos e, quando mamãe o viu, estremeceu. Ela não sabia como se desculpar diante dele. Enquanto ele falava em tom alto e rude, ela o puxou pela manga para o corredor... e não era por sua causa que ela agia dessa forma, mas, porque, no quarto contíguo, Rachel'e estava deitada com um livro em suas mãos, seus olhos sonhadores e os cabelos espalhados sobre o rosto e seu alvo pescoço... E como sempre ocorria, mamãe e as crianças terminavam de comer rapidamente o ralo cozido de favas, mas quando Rachel voltava para casa, mamãe retirava do forno uma pequena panela e colocava um pedaço de carne assada no seu prato. Ela mandava as crianças para fora da sala, e Rachel sentava-se inclinada sobre um livro e comia. Lenta e agradavelmente, ela levava a comida a boca. E quando se observava para seu calmo e charmoso rosto, era difícil dizer se ela entendia ou não o segredo da pequena panela.

\section{C}

Mais difícil ainda era tentar entender por que Rachel ficava deitada o dia todo no sofá ou sentava-se apenas para folhear uma página de um livro - a razão disser era porque ela era preguiçosa ou porque ninguém tinha qualquer importância a seus olhos. Em nossa aldeia não havia muitos rapazes, mas a cada verão algumas moças, algumas das filhas dos proprietários de casas, após concluírem o ginásio, podiam ser vistas em dias de verão ou, no inverno, depois do jantar num silencioso frio, e sob o branco luar, passeando em torno das lojas fechadas. Dentre os grupos, às vezes era possível até mesmo ouvir a voz de um 
único rapaz se levantando, mas não havia ninguém que demovesse a nossa Rachel'e a sair para um passeio amigável. E por que Rachel'e estava realmente sozinha todos os dias? Durante as refeições, quando papai encontrava-se em casa, às vezes, ouvíamos indícios sobre esse assunto.

As crianças costumavam comer assustadas e a grande velocidade, tal como costumam comer os menores depois de passar muito tempo se contentando com pouca comida, mas somente Rachel'e pegava novamente e com preguiça a colher com o alimento com sua mão branca como leite. Ela inclinava-se sobre a mesa de tempos em tempos e apoiava sua bela cabeça nela. Papai, que era rápido com tudo, chegava ao fim da refeição, enxugava seu grosso bigode com força, virava seus olhos para as pessoas sentadas diante dele à mesa e, finalmente, olhava para sua primogênita. Por um momento, papai permanecia imóvel. Seus olhos pareciam cobertos por uma névoa, ele então suspirava um longo suspiro e colocava a palma da sua pesada mão no pescoço da menina - e logo era possível ouvir o som de um grande beijo - pai e filha começavam a conversar entre si... as crianças menores que já estavam acostumadas a ver isso, continuavam comendo e, nesse instante, somente mamãe olhava para papai e dizia: - Por sua causa ela é tão mimada. Quando você viaja, ela sempre me causa problemas!

Essas coisas eram ditas por mamãe, que tinha sempre um bom temperamento, sem indignação e com a voz baixa de uma pessoa contida. Assim que papai retornava a casa após uma longa viagem, colocava na primeira gaveta da cômoda, entre um lençol e outro, algumas notas de dinheiro. Então Rachel, que já conhecia as reclamações de mamãe, a seguia com seu olhar e dizia ao pai em tom de zombaria: - Mamãe dirá a você imediatamente, que eu estou afugentando as amigas dela de casa.

E mamãe realmente começava a reclamar da filha: - Ninguém entra aqui. Ela pode deitar-se o dia todo com um livro, e não precisa de mais nada... Qualquer outra garota quer pelo menos andar do lado de fora da casa... e eu não sei se ela tem mais senso do que todas as outras quando se trata de uma conversa.

Então mamãe costumava prosseguir: - Mas se ela não agisse como uma selvagem, os outros já a teriam esquecido!

Sobre o espesso bigode do papai caía, então, uma espécie de melancolia - a ele lhe desagradava ouvir as insinuações de que Rachel era ociosa e não estava se preocupando com o sustento - então, mamãe ficava em silêncio. Papai se levantava, porque mesmo no meio das refeições ele precisava se levantar de vez em quando e andar um pouco pela sala. Seus passos pesados emitiam som, 
enquanto as crianças permaneciam sentadas à mesa, olhando e prestes a rir uns com os outros. Em seus olhos havia uma efusiva e brilhante umidade, marca característica do temperamento da nossa família. Finalmente, papai saía para a rua para ver as pessoas, então Rachel se estendia como de costume no sofá, enquanto mamãe continuava mostrando preocupação. Durante todo o tempo em que papai permanecia em casa, ela deitava para dar uma soneca, e nossa casa passava a ser dominada pelo silêncio... Assim se passavam uma hora ou duas, Rachel ainda permanecia deitada no sofá com a mesma blusa que tinha vestido naquela manhã. Um dia papai voltou da rua com convidados para beber chá e a casa voltou à vida. Uma grande garrafa brilhava sobre a mesa e duas garotas que papai convidou para conversar com Rachel falavam muito e riam alto. Rachel também se sentou à mesa e, de vez em quando, sua voz, uma voz moderada, juntava-se às gargalhadas das duas convidadas. Às vezes, Rachel'e perguntava algo como uma charada, outra vez era ela quem respondia e, a cada instante, as garotas desatavam a rir com gargalhadas desenfreadas, enquanto nossa Rachel'e disfarçava sua risada. Depois que as pessoas começavam a conversar com os conhecidos, Rachel'e, às vezes, dirigia suas perguntas ao interlocutor da conversa - pois ela adorava zombar de tudo e de todos! Ela se levantava naquele momento parecendo outra, seu rosto iluminado expressava alegria, fato que não era comum nela, então ela começava a fazer imitações e cada um de seus movimentos chamava a atenção dos convidados e todos eles riam por um longo tempo.

As duas garotas, as amigas de Rachel, eram as que riam mais e, no entanto, elas levantavam imediatamente depois da primeira xícara de chá e, enquanto a risada e o rubor do chá estavam ainda em seus rostos, elas se apressavam para sair. A esses convidados, Rachel não costumava deter. $\mathrm{O}$ mesmo ocorreu quando papai um dia trouxe para beber uma xícara de chá o contador do banco, sequer com ele Rachel insistiu para que não se fosse ou para que permanecesse conosco. Quando um elegante jovem entrou em casa e disse shalom, ele estendeu a Rachel'e sua mão com uma risada aguda de um homem bemsucedido; e, sentado à mesa, ele ria e olhava principalmente para papai - no decorrer da conversa, Rachel começou a acrescentar um comentário espirituoso após cada observação, e quando os olhos das pessoas se viravam para ela, no entanto, o jovem não quis deixar de ser o centro da conversa e começou a falar diretamente com Rachel'e. Mas logo ele enrubesceu e seu rosto, inadvertidamente, passou a expressar atenção e escuta, ele girou seu agradável bigode, respondendo: - Então, certamente. E, tal qual havia acontecido anteriormente com as duas garotas, ele também começou a mostrar impaciência, desejando sair dali após o primeiro copo de chá. 
Rachel'e não o deteve e, depois que ele se foi, ela ainda brincou dizendo: - Um homem elegante... - e todos começaram a rir de suas palavras, e, como de costume, estendeu-se novamente sobre o sofá com o livro na mão, seu rosto parecia estagnado, apenas seus olhos, que brilhavam sob longos cílios, demonstravam, ainda, um último lampejo de zombaria. Apenas observando o brilho de seus olhos era possível adivinhar que uma vida oculta se escondia em sua alma.

Somente uma vez, todos em nossa casa perceberam, Rachel acordou para viver intensamente. Meu pai, embora estivéssemos há muito tempo famintos por sua causa, era um homem com uma mente perspicaz e muito de seus lucros ele costumava gastar em viagens estranhas. Uma vez, pareceu-lhe que seria possível seduzir um certo fazendeiro a lhe vender uma fazenda a um preço baixo. Uma outra vez, ele se animou com certas máquinas quebradas, que sobreviveram num moinho queimado, mas para isso, era preciso viajar para tentar comprá-las. E, no entanto, ele estava sempre atrasado. Eis o que era interessante: meu pai que sempre caminhava a passos largos, estava sempre atrasado para todos os lugares. Seus olhos, por algum motivo, insistiam em enxergar apenas coisas que não tinham como se realizar. A venda das máquinas também acabou em nada, elas ficaram chafurdando por cinco anos fora da cidade, numa cabana onde ocorrera um incêndio, e ninguém achou que elas valessem a pena de serem compradas. Papai teve, repentinamente, uma ideia, dizendo que na cidade vizinha havia um tal de Schneerson, um judeu inteligente e avarento. Ele que emprestava dinheiro tal qual um banqueiro e se dedicava a muitas pequenas empresas que lhe davam lucros diversos, certamente estaria interessado em comprar, por um preço módico, as máquinas quebradas para as quais papai não encontrava um comprador. Usando uma das duas únicas notas de dinheiro que havia em casa, papai cobriu as despesas da viagem e foi até o homem rico. Este prestou atenção em todas as tentativas feitas por papai - papai sabia como convencer! - mas o homem não lhe ofereceu sequer um cigarro... e na hora da conversa, lá estava também o filho de Schneerson, Joseph Borisovich, era assim que papai o chamava, e ele olhou nos olhos do meu pai mais do que escutou suas palavras, e de repente virou-se para o velho e disse: - Talvez devêssemos ir até lá?

$\mathrm{O}$ velho, que naquele momento tirou um cigarro de uma caixa de prata sem demonstrar qualquer respeito por meu pai, olhou o filho de lado. $O$ filho, que herdou a força de vontade de seu pai e ainda era muito jovem e cheio de grandeza, típica de um rico filho único, dirigiu a seu pai um olhar frio e começou a perguntar ao meu pai a respeito da viagem. Então eles vieram juntos, papai e Joseph Borisovich, à noite, quando todos os membros da família 


\section{Arquivo Maaravi}

Revista Digital de Estudos Judaicos da UFMG

ISSN: $1982-3053$

estavam dormindo e, de manhã, quando meu pai saiu para beber chá e fechou cuidadosamente a porta do corredor, era possível perceber em seu rosto, que dessa vez ele trouxera um convidado especial e incomum. Quando o convidado saiu também para beber chá, ele sorriu amavelmente estendendo sua mão para minha irmã. Rachel enrubesceu ligeiramente.

Ao redor da mesa de chá reinava o silêncio. Meu pai conversou agradavelmente com o convidado e Rachel sentou-se como de costume, inclinada sobre um livro. No entanto, quando o visitante levantou-se da mesa, ele olhou para ela. Rachel, por sua vez, também olhou para Joseph Borisovich com olhos levemente arregalados e papai, que prestou atenção na troca de olhares, foi atrás de mamãe que se encontrava na cozinha e lhe disse quase sussurrando: - Esses dois não ficarão indiferentes um do outro - são pessoas da mesma estirpe. De fato, depois de uma curta conversa, Joseph Borisovich voltou e sentou-se à mesa, minha irmã sentou na frente dele e começou a falar com ele diretamente. Desde o início, se desenvolveu entre eles uma conversa sobre países e habitantes estrangeiros. Como Joseph Borisovich havia retornado recentemente de seus estudos numa cidade distante, ele começou a conversar com a segurança e a tranquilidade de um jovem que, desde a tenra idade, demonstrava inteligência. E minha irmã conseguia compreender as palavras de Joseph Borisovich, também as imagens e as ações, e ela voltava e descrevia e repetia suas anedotas. $\mathrm{O}$ tom de brincadeira foi adoçando a conversa e, dessa forma, ela foi desviando a atenção de seu interlocutor até que a imaginação dele pareceu ficar coberta por uma certa névoa, e papai que, por vezes, intervinha com alguma palavra, sentou e ouviu atentamente, e seus olhos se cobriram de umidade. A conversa ainda não tinha se encerrado, quando mamãe convidou o rapaz para o almoço. Depois, eles beberam chá e continuaram conversando, quando Joseph Borisovich sentou-se perto de minha irmã, que se reclinou parcialmente sobre o livro, e os olhos de ambos pareciam enviar uns aos outros, setas de espirituosa luz e eles também trocaram olhares luminosos. As crianças, que estavam sentadas nos cantos, ora sim ora não passava seus dedos pela borda do sofá...

Na hora do jantar, quando minha irmã silenciou apoiando a cabeça sobre sua mão branca e seus olhos observavam, sem constrangimento, Joseph Borisovich, papai lembrou-se, repentinamente, das máquinas quebradas. O percurso até a cabana foi marcado para o dia seguinte e, como a primeira vista, Joseph Borisovich não poderia decidir nada sozinho, ele ficou para dormir em nossa casa. Novamente os dois se sentaram no sofá no canto, conversando e conversando sem parar. Quando eu já começava a cochilar, ouvi do quarto ao lado, minha irmã falando com o visitante, e sua voz se estendia de forma doce e 
suave, como se no sofá ela estivesse se divertindo, a pequena Rachel'e... E depois disso, também ouvi a voz de Joseph Borisovich. A voz dele era a de um homem já conhecido da nossa família e, então, eu adormeci e agradáveis pensamentos me invadiram sobre bons e velhos tempos, muito animado por causa da chegada do rico visitante. No dia seguinte, depois que Joseph Borisovich se despediu de todos nós, ele apertou a mão do meu pai novamente, elogiando minha irmã: - Silberman, você realmente tem uma filha.

Naquela hora, minha irmã estava sentada no sofá e seus olhos observavam o interlocutor com um leve desprezo. O convidado enrubesceu por um momento, mas imediatamente acrescentou em um tom de gravidade: - Filha de uma rainha, uma princesa. Ele virou-se e olhou para minha irmã, parecendo pensativo.

\section{D}

O homem rico não comprou as máquinas, mas, depois disso, começou a ter carne todos os dias em nossa mesa e papai, ocasionalmente, entregava a mamãe notas de três rublos. Naqueles dias, papai começou a ficar conosco por períodos mais longos. Todos os dias ele trazia da rua alguns convidados e ficava com eles longamente em volta da mesa de chá, olhando para os comensais. Minha irmã passou a receber, naqueles dias, mais atenção ainda, e não passava um dia sequer, na hora de beber o chá, sem que papai lhe desse um beijo chamando-a de "minha princesa". Diariamente, ou a cada dois dias, um cartão chegava a nossa casa pelo correio. Nessa hora, papai anunciava alto para o quarto ao lado, onde Rachel, como de costume, estava deitada na cama lendo um livro: - Um cartão de Joseph Borisovich! Rachel, porém, nunca se dava ao trabalho de emitir uma resposta, nem pedia para que lhe dessem o cartão.

Um dia, Rachel estava se penteando parada diante do espelho, quando papai veio às pressas da rua e em sua mão ele erguia uma carta assinada: - Eis aqui uma carta para você de Joseph Borisovich! Minha irmã pegou a carta com uma mão e com a outra ela continuou a arrumar seu cabelo. Após um tempo, papai, já aflito, disse a Rachel: - Leia por fim, o que ele escreveu? Rachel decidiu fazer a vontade do papai e, com os olhos abertos, mas já com a sombra do sono neles, passou seus olhos pela carta que estava escrita na frente e atrás da folha. Inicialmente, papai olhou para Rachel, depois recuou um pouco e, após um momento, afastou-se e não voltou a perguntar mais nada. Em seguida, durante o inverno, papai deixou de entregar as cartas pessoalmente a Rachel, enviandoas pela mão dos outros filhos. Apenas uma vez, quando papai se encontrava longe de casa, ele perguntou à esposa a respeito de Rachel: - Diga-me, em nome de Deus, se Rachel continua recebendo cartas com frequência... O cartão 


\section{Arquivo Maaravi}

Revista Digital de Estudos Judaicos da UFMG

ISSN: $1982-3053$

do papai chegou antes da Páscoa e, com o passar do tempo, todos os membros da casa tornaram-se testemunhas da felicidade de Rachel.

A Páscoa chegou em nossa casa com dificuldade e lentidão. Papai enviava, ocasionalmente, enquanto estava longe, três rublos embalados dentro das cartas e uma módica quantidade de matzáa que foi trazida a nossa casa em vésperas da festa e ficou fechada no guarda-roupa. Enquanto isso, Rachel deitou-se como de costume no sofá, balançando seu pé e parecendo desejar jogar fora o sapato desgastado e puído que ela calçava... Apenas dois dias antes do início da festa, papai voltou para casa trazendo consigo algumas notas de dinheiro, fazendo isso, como de costume, à vista de todos. A época da Páscoa não é um tempo de amortização de dívidas e, portanto, sobre nossa mesa do Seder ${ }^{3}$ havia mais uma garrafa de vinho e Rachel calçava sapatos novos de verniz. Na manhã seguinte, a festa se iniciou em nossa casa no meio de um nevoeiro iluminado e nós estivemos, todos os oito dias da Páscoa, entorpecidos. Do lado de fora da casa, havia bastante lama e uma chuva fraca caia infiltrando-se sem cessar. Para os membros da família, essa época era de uma alegria especial, uma espécie de descanso dos humildes, época em que todos podiam desfrutar da presença do papai em casa. Mamãe recolheu de todos os esconderijos roupas limpas para os filhos e Rachel também lavou e limpou ajudando com os preparativos da festa.

Quando a festa chegou, após a eliminação do chametz, ${ }^{4}$ Rachel ficou junto à janela observando a rua. Era difícil ver através dos vidros molhados, por isso, ela apertou sua face vermelha sobre uma das vidraças. Ao se afastar da janela, pareceu mergulhada em pensamentos, caminhando desde então até o anoitecer como num cochilo, e só à hora do anoitecer, quando papai saiu para ir à sinagoga, ela trocou a roupa vestindo-se de festa. Quando papai voltou da sinagoga, ele pronunciou a bênção da festa em voz baixa, olhando para Rachel. Ao celebrar o Seder, papai colocou a mão de Rachel sobre a Hagadá ${ }^{5}$ e sua própria palma da mão ele colocou sobre as costas da filha. Com uma tênue tristeza, ele leu a Hagadá, observando de vez em quando sua filha mais velha. Ao concluir o Seder, depois que as crianças foram se deitar e mamãe estava prestes a adormecer, Rachel ainda estava sentada com os olhos bem abertos, virando-se, com frequência para a janela, e, após cada movimento de sua cabeça, papai também virava a sua. De repente, ouviu-se uma batida na janela,

${ }^{2}$ Matzá é o pão ázimo que se come durante os dias da festa de Pessach.

${ }^{3}$ Seder é a cerimônia que dá início à celebração de Pessach.

${ }^{4}$ Chametz é todo alimento que contém fermento e que deve ser removido da casa antes do início de Pessach.

${ }^{5}$ Hagadá é o livro que é lido na noite da Pessach e que contém uma série de narrativas alusivas à saída dos hebreus do Egito. 
Rachel e meu pai olharam um para o outro e ambos se viraram em direção à porta. Rachel parou diante do corredor e ouviu papai abrindo e fechando rapidamente a porta do lado de fora, ele acendeu um fósforo permanecendo na cozinha por um instante. Mas, repentinamente, papai entrou anunciando com sua voz alta e trémula: - Eu sabia... uma carta para você!

Rachel, que voltou para a mesa, não disse uma só palavra e começou a rasgar o envelope rapidamente. Suas bochechas recobraram o rubor e seus olhos brilharam. Ela não percebeu como papai recuou um pouco e se inclinou sobre a Hagadá. Ele começou a ler na frente de todos quando, repentinamente, a carta caiu das mãos de Rachel, ela aproximou-se do pai e colocou lentamente sua cabeça sobre seu ombro. Os olhos aquilinos do papai brilhavam, ele pegou a carta inserindo-a dentro do envelope, entregou o envelope para Rachel e disse:

- Esconda-o.

Rachel dobrou a carta e a escondeu entre o cinto de seu vestido, sua face queimava como fogo vermelho enquanto ela fechou a borda do cinto. Nesse momento, mamãe sacodiu levemente a cabeça, seu rosto cansado mostrou um leve sorriso e ela falou com a franqueza de uma pessoa parcialmente acordada: - Você realmente escolheu para si um noivo bonito.

Rachel se levantou da mesa e, ao passar, colocou sua mão sobre a boca da mãe. Mamãe ainda sonolenta, beijou silenciosamente a pequena palma da mão e Rachel foi se deitar.

Todos os membros da família, até mesmo Reizeleh, de cinco anos de idade, se tornaram, após aquele Seder, mais alegres. Mais tarde, quando papai partiu para as longas jornadas de verão, Rachel costumava perguntar de vez em quando a um de nós, se o carteiro havia passado na rua. Quando uma das crianças corria confusa e trazia uma carta, Rachel a recebia com um leve e moderado movimento de mão. Quando ela escrevia uma carta de resposta, colocava-a, na maior parte das vezes, quando o envelope já estava fechado, sobre a mesa, deixando-a lá por um bom tempo. Quando uma das crianças se dava conta da presença daquela carta, imediatamente a entregava para mamãe dizendo: Rachel já escreveu. Todos os membros da família procuravam por um selo para o envio da carta, enquanto Rachel penteava seu cabelo diante do espelho, como se a carta não fosse dela.

Aconteceu uma vez que a pequena Reizeleh demonstrou grande inteligência. As crianças brincavam do lado de fora, famintas e quietas como de costume. De repente, Reizeleh se separou do grupo e correu para encontrar mamãe que 
estava voltando do mercado. Imediatamente, a pequena retornou e, entrando rapidamente na sala, disse: - Rachel, mamãe trouxe!. Minha irmã mais velha virou a cabeça para Reizeleh e a viu em pé, ofegante, e com seu pequeno dedo ela apontava para o envelope fechado que, naquele momento, encontrava-se sobre a mesa.

Uma vez, por ocasião da festa de Shavuot, ${ }^{6}$ papai retornou para casa e mamãe assou uma chalá ${ }^{7}$ com canela. Nos dois dias da festa, houve uma onda de intenso calor, um grande vento soprou e nuvens de areia apareceram nas janelas. Apenas no final da festa, ao anoitecer, quando mamãe já estava deitada, papai saiu de casa e sentou-se no banco, que estava em frente da casa, e ali ele permaneceu por um longo tempo com Rachel. Ele, em conversa com ela, disse: - Eu estive em muitos lugares dessa vez: se não fosse a festa, eu certamente teria...

Rachel tocou a mão dele e disse:

- Olhe, pai, veja como está brilhando aquela estrela, lá atrás da árvore, parece uma pequena lanterna...

Papai, que se interessava pelo céu e pelas estrelas, olhou para a lanterna celestial e seus olhos brilhavam com uma umidade escura... Mas ele imediatamente retornou ao assunto anterior:

- Eu realmente pensei em ir até lá, talvez algo venha a sair daquele negócio das máquinas.

Rachel começou a rir e papai a puxou e lhe falou com franqueza:

- Há algum motivo para rir? Se eu estivesse lá, eu poderia ter trazido Joseph Borisovich até aqui.

A mão de Rachel não se afastou do joelho de papai e ele entendeu isso como um bom sinal.

- Tudo depende da sua opinião, Rachel, mas talvez seja interessante que você escreva para Joseph Borisovich, e peça a ele para vir até nós. Em nome dos pais é claro, como é habitual...

Enquanto falava, ele brincava com os dedos de Rachel, persuadindo-a a ouvi-lo. Mas Rachel caiu na gargalhada de novo e, rindo, levantou-se do banco.

${ }^{6}$ Shavuot é a festa de Pentecostes que ocorreu exatos 50 dias após Pessach.

${ }^{7}$ Chalá é um pão trançado que se come em ocasiões festivas. 
- Do que você está rindo essa noite? A janela está aberta, você ainda acordará mamãe.

Papai deslizou a mão sob seu grosso bigode.

- Diga-me, por que você está rindo?

- O próprio Joseph Borisovich escreveu que virá em breve, Rachel respondeu e suspirou após o riso.

Papai parou de falar, ele não sabia quão longe as coisas poderiam chegar! Ele pegou a mão de Rachel e levantou sua filha querida do banco e lhe disse:

\section{- Vá para a cama!}

Depois, ele se preparou para entrar no quarto. Mamãe ainda não havia adormecido. Depois de alguns dias, quando no bolso de papai havia dinheiro apenas para a próxima viagem, chegou em casa, de repente, um telegrama para Rachel. Como de costume, ela, que estava deitada na cama, estendeu sua mão para pegar a folha e, sem querer, a manga da sua ampla blusa deslocou-se e seu braço branco como a neve ficou descoberto. Ao ver o braço de sua filha, papai apressou-se em adivinhar as novidades:

- Quando Joseph Borisovich virá?

- Hoje! Rachel respondeu rindo, soltando a seguir a folha do telegrama.

Então todos nós vimos, como papai colocou todo o dinheiro que havia em sua carteira nas mãos de mamãe. Naquela noite, Rachel foi até a estação para encontrar o convidado. Vestindo uma camisa branca com duas fileiras de botões pretos, Rachel parecia esplendorosa e, ao vê-la, os olhos de mamãe encheram-se de lágrimas. No final da tarde, quando nos sentamos todos à mesa, Rachel e Joseph Borisovich não conversaram muito quando da primeira vez, mas se entreolharam e sorriram sem palavras, parecia como se fosse para eles difícil dialogar diante da nossa presença. Apenas papai falou em voz alta. Ao final da refeição, papai afastou-se para conversar com Joseph Borisovich, chamando-o de vez em quando para lhe dizer com carinho: - Meu querido, Joseph Borisovich. O convidado, cujos olhos negros transpareciam um tipo de sabedoria especial de pessoas ricas, franzia o cenho ao responder para papai e, também para às crianças, que estavam sentadas animadamente à mesa, e ele soltou uma leve risada após alguns minutos. Somente para Rachel, ele olhava de forma especial. E assim foi no dia seguinte e também no outro dia - Joseph Borisovich franzia a testa para papai, mas seu rosto se iluminava ao ver Rachel. 
No terceiro dia, ao anoitecer, Rachel estava reclinada sobre o sofá, ela havia retornado após um passeio em companhia de Joseph Borisovich. Seu rosto parecia cansado e um dos botões de sua blusa estava aberto. Joseph Borisovich sentou-se ao lado do sofá e seu joelho tocou no joelho de Rachel. À noite, papai e Rachel acompanharam o convidado que retornou para sua cidade. Antes de deitar, papai caminhou até o quarto e disse para mamãe, que estava já deitada na cama: - Eles se separaram com um beijo... Joseph Borisovich assegurou que nos visitará em algumas semanas.

Depois da partida de Joseph Borisovich, papai também partiu, mas mamãe teve que ir, primeiro, até a casa de Moshé Ytzchak, para penhorar alguma coisa. E mais uma vez ficamos abatidos em meio a dias de tristeza, dias típicos de uma casa pobre. As crianças famintas rondavam a casa quietas e distantes e, em seus olhos, tremulava uma centelha de espanto. Rachel retomou o hábito de se deitar, e cada vez que o fazia, uma risada aparecia em seus lábios, e sobre os joelhos, ela às vezes colocava uma carta fechada que havia recebido pela manhã da parte de Joseph Borisovich.

\section{$\mathbf{F}$}

Lentamente, as cartas pararam de chegar. O calor do mês de Tamuz passou e Joseph Borisovich não apareceu como havia prometido. Uma vez, pela manhã, ouviram-se da sala passos incomuns, mas logo ficou claro que eram os pesados passos do papai. Naquele mesmo dia, à hora do almoço, Rachel sentou-se à mesa sem soltar, nem por um momento, seu livro, e meu pai tentou falar com ela: - Como vão as cartas?

Rachel pareceu encolher-se no banco e nada respondeu.

- Joseph Borisovich ainda não nos procurou - há algum um motivo para isso? Perguntou meu pai, baixando a voz.

Rachel levantou a cabeça e começou a rir.

- Qual é a razão da risada? Meu pai perguntou.

- Ele espera que eu vá até ele - respondeu Rachel, olhando para papai rangendo os dentes num pedaço de pão.

Ficou claro para todos que papai ficara incomodado. Depois de um momento, ele se virou e perguntou:

-Até hoje as cartas que ele escreveu estavam certas, corretas? 
Rachel deu de ombros para a pergunta e inclinou a cabeça para seu livro. A refeição terminou em silêncio e, à tarde, papai foi dormir. Ao anoitecer, na hora de beber o chá, papai trouxe um convidado da rua - o elegante contador, que fazia um ano que não vinha à nossa casa. Desde o início, o convidado desatou a falar enrolando seu bigode, mas então ele começou a piscar para Rachel e a responder "sim" e "assim" diante da fala fluente de Rachel. Ficou evidente que minha irmã estava falando, deliberadamente, e, mesmo durante a despedida, após a conclusão da visita, Rachel estendeu sua mão para Buchalter em uma espécie de moderação especial, que expressava grande gentileza. Ela levantouse e ficou parada, nesse momento, ao lado da janela, o sol poente lançava luz em seus olhos e envolvia seu pescoço branco como que numa renda avermelhada transparente. Buchalter virou-se várias vezes para ir embora e disse:

— Vamos nos ver de novo! Até mais! Até mais!

Alguns dias depois, ele voltou. Rachel estava sentada num canto escondido ao lado da janela e, enquanto falava com o contador, afundou-se no sofá. Depois, ela acenou com a carta fechada que havia recebido e guardado por vários dias. Um profundo silêncio instaurou-se na sala, somente ouvia-se o barulho do rebanho, que voltava do pastoreio passando diante da janela aberta, e o mugido do gado interrompia as suaves palavras de Buchalter que, naquela hora, estava segurando a ponta do xale de Rachel, que pendia sobre o ombro. A manada se afastou lentamente e, da rua, começou-se a ouvir a voz de Reizeleh, que estava brincando lá fora. De repente, a menina subiu na prateleira ao lado da parede e colocou a cabeça para dentro da janela. Por um momento, a garota sorriu para a irmã mais velha, mas quando viu a carta fechada na mão de Rachel, pronunciou palavras claras em sua voz estridente:

- Eu irei para a loja e trarei um selo! Lá eles vão me dar!.

Rachel olhou para a criança com olhos arregalados, depois começou a rasgar a carta em pequenos pedaços que ela foi ocultando lentamente na beira do seu xale, e, sentando-se, começou sacudindo o fardo de pedaços de papel por um longo tempo como se fosse um jogo. Somente depois que Buchalter foi embora, ela aproximou-se da janela e espalhou os pedaços de papel ao vento. A rua já estava escura no crepúsculo.

À noite, Rachel sentou-se no banco em frente à casa e papai começou a andar pesadamente pelo quarto escuro, onde se encontrava a cama de Rachel. Finalmente, ele também saiu e, por alguns minutos, ficou em silêncio ao lado da filha. À luz do luar, Rachel olhou para ele e seu rosto estava sorridente. 
- Eu sou culpado de tudo! Papai sussurrou com voz rouca e caiu sobre o banco.

- Olha, pai, a estrela brilhante que está atrás da árvore - parece uma pequena lanterna.

- Oh, Rachel'e, Rachel'e, suspirou papai, e as palmas das suas mãos cobriam seu rosto.

- O que te acontece, papai, por que você está chorando? Aproxime seu grosso bigode e eu enxugarei suas lágrimas.

- Por que você está rindo de minhas palavras?... E eu não deveria saber que um rapaz como ele só iria atrás de dinheiro? Mas eu pensei - ele te chamou de princesa...

De repente, Rachel se moveu e ergueu sua cabeça. Ela empurrou papai para o lado e de sua boca se escutaram risos exaltados e palavras fragmentadas:

- Filha de uma rainha? Uma princesa?

E sua risada aterrorizou mamãe, que já estava deitada na cama.

Tradução: Gabriel Steinberg*

Recebido em: 24/09/2018.

Aprovado em: 10/10/2018.

\footnotetext{
** Doutor em Língua Hebraica e Professor do Departamento de Letras Orientais da Faculdade de Filosofia, Letras e Ciências Humanas da Universidade de São Paulo.
} 